\title{
The Imposition of Income Tax on Contract Investment Collective-Asset Backed Securities Transactions in Indonesia
}

\author{
Fatmah Shabrina ${ }^{1}$, Wulandari Kartika Sari ${ }^{2}$, Milla Sepliana Setyowati ${ }^{3}$ \\ \{shabrinasymln@gmail.com ${ }^{1}$, ks.wulandari87@gmail.com², milla.s.setyowati@gmail.com ${ }^{3}$ \}
}

Department of Fiscal Administration, Faculty of Administration Science, University of Indonesia ${ }^{1,2,3}$

\begin{abstract}
Asset-Backed Securities is securities consisting of a collection of financial assets in the form of bills such as credit card bills, leasing bills, housing loans, toll-road revenues, and so on. It is a high-level investment instrument with characteristics such as fixed income securities where investors get income to benefit from investment in CIC-ABS. This study aims to analyze the imposition of taxes on CIC-ABS transactions in Indonesia, using a qualitative approach and descriptive research type which conducted from February 2020 to July 2020. In the provisions of income tax, CIC-ABS is considered "other forms of corporate", so that the income tax aspect is the same as that of a corporate taxpayer. One of CIC-ABS income comes from the margin it receives from Originator. The margin is calculated in CIC-ABS income, and Withholding Income Tax Article 23 is deducted because it is categorized as interest.
\end{abstract}

Keywords: Asset-Backed Securities, Margin Income, Withholding Income Tax

\section{Introduction}

Funding for the company is crucial to maintain its existence, especially in business development or expansion. Various ways are sought by the company to obtain appropriate funding sources, both funding sources that are permanent (long term) or temporary (short term). Sources of funding for businesses can be obtained from two, namely, internal capital and external capital [1]. Sources of internal capital funding come from, among others, retained earnings, while external sources of capital come from loans to banks or the capital market. Each of these funding, especially funding through debt has risks that can be taken into consideration. Being aware of the risks involved in making loans to banks in the form of highinterest rates requires another alternative in business funding. To maintain the long-term availability of funds and increase its solvency, companies should not only pay attention solely to the level of debt and capital owned but also look at the company's assets. Especially for companies whose assets are mostly in the form of receivable assets [2].

Since its first appearance in the 1970s in America, asset securitization has been present in Indonesia in the same era. Its development has been rising since the end of 1997, a response to the economic crisis that occurred in Indonesia. This is the impact of weakening bank liquidity. Asset securitization is an alternative for companies that have potential assets to improve their financial position. Asset securitization is usually carried out on potentially good assets to meet funding needs.

The term asset securitization came to be known as Asset-Backed Securities (ABS) or Efek Beragun Aset (EBA) in Indonesia. Asset-Backed Securities are securities, whether they are 
debt obligations, participation letters, or derivatives issued by a securities issuer. Asset securitization products are called Asset-Backed Securities [3]. This refers to the mechanism that every fulfillment of obligations in securitization or securities is guaranteed with assets. Securitized assets can be commercial paper, leases, credit card bills, and other financial assets. Article 1 Number 7 OJK Regulation Number 6 the Year 2017 states that "Asset-Backed Securities are Securities issued by KIK-EBA whose portfolios consist of financial assets" [4]. Therefore, the issuance of EBA in Indonesia can only be done through an Asset-Backed Securities Collective Investment Contract (KIK-EBA).

Based on taxation provisions, the CIC-ABS is classified as a Corporate Tax Subject, which is the same as other forms of corporates. The implications of this stipulation place the CICABS must meet the Income Tax obligations, which in its implementation are represented by the Custodian Bank as the manager of all income arising in the EBA transaction. One of the Income Tax obligations which CIC-ABS must fulfill is Income Tax Article 23 which withheld from the margin received by CIC-ABS from the Originator. The withholding of Income Tax Article 23 stipulation causes CIC-ABS to have a continuous overpayment. It becomes the main issue which triggered this study.

This study aims to analyze the imposition of taxes on CIC-ABS transactions in Indonesia, using a qualitative approach and descriptive research type. The result of this study are different from the previous studies because it will highlight the implementation of the imposition of income tax on EBA transactions and its impact on CIC-ABS.

\section{Literature Review}

The asset securitization studies used to describe the asset securitization transactions which leads to the existence of CIC-ABS in Indonesia. This CIC-ABS studies will explain the CICABS form implemented in Indonesia and its treatment from the tax law perspective as Corporate Tax Subject. The income tax studies completed the other studies to provide the income tax basis theories and law used in Indonesia. The previous studies used are "Tax Treatment of Securitisations of Receivables" by Bhattarai and Baxi (2002) [5], "Asset Securitization is as an Alternative Strategy in Financing at Bank XYZ" by Amelia (2011) [6], "Sekuritisasi Aset Lembaga Pembiayaan dan Pengembangan Pasar Secondary Mortgage Facility dalam Rangka Pendalaman Pasar Keuangan Indonesia" by Suselo, Soekro, and Nugraha (2013) [7], and "Corporate Taxes and Securitization" by Han, Park, and Pennacchi (2015) [8]. These studies did not provide the issue related to the imposition of income tax for CIC-ABS transactions in Indonesia, which leads to this study.

This study was analyzed by using various studies related to asset securitization, CIC-ABS, and income tax. Asset securitization is a financing technique by collecting and packaging several financial assets in the form of bills that occur in financial transactions or trade transactions. Furthermore, asset securitization is a mechanism whereby loans, installment sale, and purchase contracts, leases, receivables, and various other types of illiquid assets are packaged into capital market effects [9]. Frost explained that asset securitization is a financial innovation in which companies sell financial assets to specially formed entities that can reach financial markets at a certain point [10]. An innovative step for lenders to raise funds in the capital market by selling future cash flow receivables for their assets [11].

There are 3 (three) types of the basic structure of asset securitization, namely, Collateral Debt Obligation, Pass-Through Obligation, and Pay-Through Obligation [12]. The provisions 
for issuing EBAs in Indonesia adopt the structure of Pay-Through Obligation. The company's asset securitization process is carried out by a Special Purpose Vehicle (SPV) [2]. SPV is a container to accommodate investor funds, which subsequently use these funds to purchase financial assets from original creditors [13]. Issuance of asset-backed securities in Indonesia is done through a Collective Investment Contract. This form of investment is more desirable than direct investment, with consideration of economic efficiency and other benefits obtained with this scheme [14]. The OECD states that implementing the taxation aspects of collective investment contracts is generally different for each country. Some countries do not impose a tax on collective investment contracts, while others impose taxes by providing facilities in the form of a reduction on the tax base.

Indonesia imposes income taxation for CIC-ABS transactions as Indonesia implementing "S-H-S Income Concept" which put forward by Schanz, Heig, and Simons to define "income" on a tax basis. S-H-S Income Concept is a concept of income that affects tax policies in various countries because it is considered to most reflect justice and applicable [15].

\section{Method}

This research was conducted with a qualitative approach. The qualitative data collection was carried out through field studies and literature studies. The field studies were done to obtain primary data conducted by doing an in-depth interview with various informants consisting of the Directorate General of Tax, Fiscal Policy Agency, CIC-ABS representative, tax practitioner, tax academic, and the Financial Services Authority. The literature studies were done to obtain secondary data. The results of both studies were analyzed with the relevant theories. It will be presented in the form of research result and analysis and conclusion to answer the research question and includes recommendations that are relevant to the issue raised.

This research also has been enhanced with a focus on the issue of implementation of income tax collection on income that arises from the CIC-ABS transactions and how it affects the parties concerned. It involves various informants, especially the CIC-ABS representative itself so who can provide relevant information related to the issue. This research was carried out from February 2020 to July 2020 to gather the information relevant to the current condition.

\section{Result And Discussion}

\subsection{CIC-ABS Transactions in Indonesia}

Provisions of Article 2 Paragraph (1) of Law Number 36 the Year 2008 concerning Income Taxes [16] and Decree of the Director-General of Taxes Number 147/2003 [17] stipulate CICABS as Corporate Tax Subject in Indonesia, which in the condition that subjective and objective tax requirements are met, becomes a Corporate Taxpayer. Related with this, several income tax obligations that CIC-ABS must fulfill arises, namely Corporate Income Tax and withholding income tax related to CIC-ABS transactions with other parties. In an EBA transaction, the income received by KIK is the margin given by the Originator to the EBA. $\mathrm{CIC}-\mathrm{ABS}$ was formed based on the needs of the Originator. An originator who needs long 
term funding will sell off his financial assets to CIC-ABS. Then, CIC-ABS buys it using funds from investors (holders of participation units). Later, the Originator must repay the money he received in the amount of the loan principal and margin. The intended margin is the payment of interest or other types of income other than the principal payment paid by the Originator or debtor to KIK EBA, which will then be distributed to investors. Illustration of principal and margin return transaction flow in CIC-ABS transactions can be seen in Figure 1.

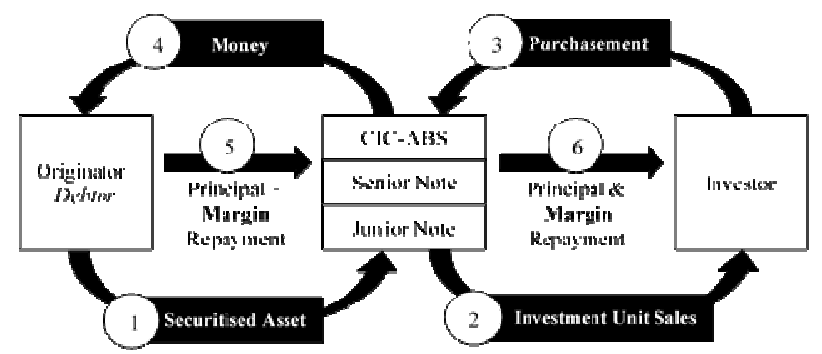

Fig.1. CIC-ABS Transactions [18]

Figure 1 can be explained as follows [18]:

1. The Originator (owner of the asset) transfers the rights to the selected assets to be securitized to CIC-ABS. This transfer is a "sale off" (true sale).

2. CIC-ABS sells unit participation to investors (holders of the CIC-ABS unit Fixed Cash Flow (Senior) and holders of the unit CIC-ABS Non-Permanent Cash Flow (Junior).

3. Investor purchases a participation unit to CIC-ABS.

4. CIC-ABS submits the proceeds of the sale of the participation unit to the Originator.

5. The Originator will make a principal return accompanied by a certain margin to CIC-ABS at the agreed time.

6. Payment from the Originator will be returned to investors after deducting costs, such as service fees paid to the Investment Manager, Custodian Bank, etc.

Based on the explanation flow of Figure 1, it appears that there are at least two transaction flows. The first stream is the purchase of securities by investors as a form of participation, and CIC-ABS forwards funds from investors to the Originator. The second flow is formed when the Originator pays back the loan principal along with a margin on loan funds obtained from KIK EBA, then KIK EBA will distribute the profit margin to investors. In the first stream, there is a "sale off" transaction or actual sale of assets transferred from Originator to CICABS. In this case, the investor is the first party to provide funds by buying EBA participation units from CIC-ABS. Then, CIC-ABS, as the second party and the intermediary party receives investment funds from investors and gives them to Originator, who is the last party in the flow of funds. These funds will be received by the Originator and used according to their needs. The second stream starts from Originator as the first party. In return, the Originator will return the principal amount he received from investors through CIC-ABS plus margin. Then, as a second party and an intermediate party, CIC-ABS receives the principal loan return and margin to be forwarded to the last party, namely the investor. In the end, those who receive benefits and enjoy margin return results are investors.

\subsection{Withholding Tax for Margin or Interest Received by CIC-ABS}

From the taxation point of view, the margin received by KIK EBA from the Originator is subject to Article 23 Income Tax deduction. This margin is based on the same characteristics 
as the interest income for transactions made by CIC-ABS, including capital transactions. Therefore, the margin paid is subject to Article 23 Income Tax at a rate of $15 \%$ as stipulated in Article 23 paragraph (1) letter 'a' number 2 of the Income Tax Law, through a tax withholding scheme by a third party, which in this case is the Originator.

The margin received by CIC-ABS is the net value after tax. Withholding Income Tax Article 23 that has been deducted by the Originator can then be used as a tax credit for CICABS because it is provisional (temporary). The approach used in this deduction system is an approach that treats Article 23 income tax cuts as an installment of tax payments (advance payment) that can be credited against all tax debts calculated at the end of the tax year. Thus, Article 23 of Income Tax, which has been deducted by the Originator can be credited by CICABS at the end of the year when calculating the owed Corporate Income Tax in accordance with Article 28 paragraph (1) letter) c 'of the Income Tax Law.

\subsection{Impact of Withholding Tax on Margins or Interest Received by CIC-ABS}

Withholding PPh Article 23 at a rate of $15 \%$ on the margin received by CIC-ABS has its impact on CIC-ABS. CIC-ABS's primary income comes from principal and margin payments by Originator, which, will be forwarded to investors as beneficiaries. Income received by KIK EBA is first reduced by costs, such as payments to investors to Investment Managers, Custodian Banks, and other services, including payment of returns to investors on principal and margins. This calculation scheme implies that the CIC-ABS Taxable Income becomes 0 (zero) because all income received will be distributed to the parties involved, including investors. The effect is then, the amount of Corporate Income Tax payable CIC-ABS becomes 0 (zero) by multiplying the Taxable Income with the applicable Article 17 Corporate Income Tax rate, as illustrated in Table 1.

Table 1. Illustration of Calculation of Income Tax for CIC-ABS

\begin{tabular}{lr}
\hline \multicolumn{1}{c}{ Description } & Amount $+/(-)$ \\
\hline Penghasilan Kena Pajak (a) (taxable income) & 0 \\
Income Tax (b = a x Income Tax Rate) & 0 \\
Domestic Tax Credit (c = Income Tax Article 23) & $(7,5)$ \\
Underpaid Taxes / (Overpaid) & $(7,5)$ \\
\hline
\end{tabular}

The illustration in Table 1 shows that CIC-ABS still has the right to credit Article 23 Income Tax at a rate of $15 \%$ deducted by the Originator for the margin previously received by CIC-ABS. The existence of the tax credit causes the PPh-EBA Agency Income Tax to be overpaid. The calculation process like this will repeat every year until the last year of the existence of CIC-ABS. This overpaid status will occur continuously every year until the final year of the establishment of CIC-ABS. This is because every year from its inception until the end, CIC-ABS receives gross income only in the form of payment of the principal and margin paid by Originator, which will then be forwarded to the investor.

The overpaid status experienced by CIC-ABS carries the potential for tax audits to be carried out. This is a consequence that CIC-ABS must face when applying for tax refund overpayment. This cash flow is required by KIK EBA to make payments to related parties in EBA transactions, including margins to holders of investment units and service providers. However, implementation in the field of inspection due to overpayment can be carried out within a period of no later than 12 months since the tax return with the overpayment status is submitted a refund of tax overpayment as regulated in Article 17B paragraph (1) of the KUP Law. Given the length of the Examination process that CIC-ABS must pass to receive 
restitution, this will impact the disruption of CIC-ABS liquidity. CIC-ABS must immediately distribute the principal loan and margin payments to the holders of participation units and service providers according to the time agreed in the Prospectus as explained by the resource person [19], [20].

The status of overpayment experienced continues to encourage CIC-ABS to submit applications for Free Certificates (SKB) to the Director-General of Taxes [21], as stipulated in Article 3 letter ' $c$ ' PER-21/2014. Referring to the provisions mentioned above, the prerequisites for submitting SKB applications, namely CIC-ABS, must experience overpaying in advance. The SKB submission does not adequately address the impact experienced by CICABS. It still has to face the risk of liquidity that is disrupted due to overpayment and face an inspection that can take no later than 12 months, at least for the first year of the EBA's founding.

Another impact experienced by CIC-ABS due to withholding tax on the margin it receives is economic double taxation, a phenomenon of taxation of the same income more than once. This double taxation occurs on margin income received by CIC-ABS. When CIC-ABS received the income, the Originator had deducted Article 23 Income Tax at a $15 \%$ rate. Then, CIC-ABS forwards income payments to holders of the CIC-ABS Fixed Cash Flow equalization unit, and the income is deducted by Final Income at a rate of $15 \%$ at the investor level stipulated in PP-55/2019 [22] (Article 5 paragraph (2) KEP-147/2003 regulates that the income of the holders of the CIC-ABS unit of Fixed Cash Flow equal to the income of bonds). An illustration of this double taxation can be seen in Figure 2.

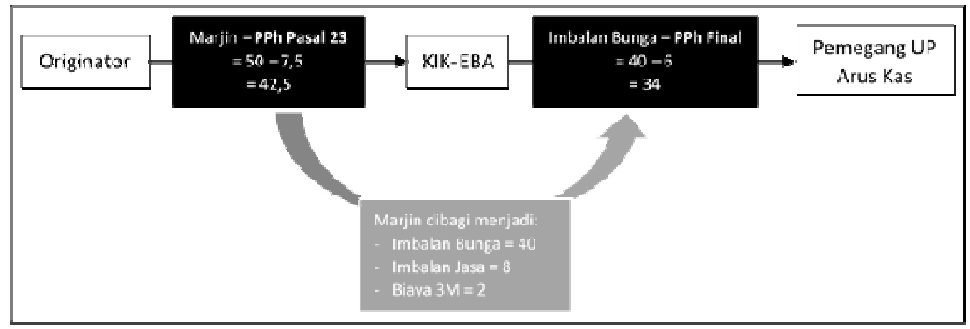

Fig.2. Illustration of Double Taxation on CIC-ABS Transactions

Figure 2 shows that Article 23 Income Tax has deducted the margin income received by CIC-ABS at $15 \%$ of gross $(50 \times 15 \%=7.5)$ by the Originator. Then, when the margin is distributed to the holders of the CIC-ABS Fixed Cash Flow unit in the form of interest rewards, the income is again deducted by Final Income at a rate of $15 \%(40 \times 15 \%=6)$. This shows a double tax deduction on the same income, the margin received by CIC-ABS, which will be forwarded in return for interest for holders of the CIC-ABS Fixed Cash Flow unit.

\section{Conclusion}

Margin income received by CIC-ABS from the Originator is deducted by Article 23 Income Tax at a rate of $15 \%$ because it is equal to interest income and can become a tax credit at the Corporate Income Tax level. The tax deduction has implications for the position of the CIC-ABS Corporate Income Tax being continuously overpaid each year until the collective investment contract is dissolved. For this overpayment, CIC-ABS will file a tax refund that must be preceded by a tax audit. 
Considering that the overpayment process has reached 12 months since the Corporate Income Tax Return has been reported, this will impact the disruption of CIC-ABS liquidity, which will affect the payment of interest payments to investors and payment for other services. Although CIC-ABS can apply for a Free Certificate (SKB), overpayments in the first year must still be processed for inspection before tax refund is approved. Besides, the margin received by CIC-ABS will ultimately be distributed to investors and parties involved. At the level of the holder of the CIC-ABS Unit for Fixed Cash Flow, the interest received from CICABS will also be deducted from the Final Income Tax. In this case, economic double taxation occurs on the same income at different levels.

This study recommends that the government could consider exempting the withholding tax of the margin received by CIC-ABS. On the other way, the government could also provide accelerated restitution for CIC-ABS by implementing Article 17C of the GTL (UU KUP) so that no restitution is hampered and disrupts the liquidity of CIC-ABS. Regarding do the double taxation issue arises, it is better if the taxation for the CIC-ABS transactions is done only at one level, wether it the CIC-ABS itself or the investors.

\section{References}

[1] A. Sawir, Kebijakan pendanaan dan Restrukturisasi Perusahaan. Jakarta: PT Gramedia Pustaka Utama, 2004.

[2] V. I. Dewi, "Sekuritisasi Aset sebagai Peluang Bisnis dan Peningkatan Solvabilitas Perusahaan," Bina Ekon., vol. 10, no. 1, pp. 86-95, 2006.

[3] P. P. Sugarda, "Sekuritisasi Aset dalam Kontrak Investasi Kolektif Beragun Aset di Indonesia," Mimb. Hukum-Fakultas Huk. Univ. Gadjah Mada, vol. 20, no. 1, pp. 35-49, 2008.

[4] Peraturan Otoritas Jasa Keuangan Nomor 65/POJK.04/2017 tentang Pedoman Penerbitan dan Pelaporan Efek Beragun Aset Berbentuk Kontrak Investasi Kolektif. Republik Indonesia, 2017.

[5] Y. Bhattarai and D. Baxi, "Tax Treatment of Securitisations of Receivables," Int. Bur. Fisc. Doc. J. "Derivatives Financ. Instruments", 2002.

[6] I. L. Amelia, "Asset Securitization is as an Alternative Strategy in Financing at Bank XYZ," Universitas Indonesia, 2012.

[7] S. L. Suselo, S. R. I. Soekro, and R. A. Nugraha, "Sekuritisasi Aset Lembaga Pembiayaan dan Pengembangan Pasar Secondary Mortgage Facility dalam Rangka Pendalaman Pasar Keuangan Indonesia," WP/5/2013, 2013.

[8] J. Han, K. Park, and G. Pennacchi, “Corporate Taxes and Securitization,” J. Finance, vol. 70, no. 3, pp. 1287-1321, 2015.

[9] A. K. Bhattacharya and F. J. Fabozzi, Asset-Backed Securities. Pennsylvania: Frank. J. Fabozzi, Associates, 1996.

[10] C. W. Frost, “Asset Securitization and Corporate Risk Allocation,” vol. 72, no. 1, pp. 101-157, 1997.

[11] J. C. Hu, Asset Securitization. John Wiley \& Sons (Asia), 2011.

[12] A. H. Manurung and E. S. L. Nasution, Investasi Sekuritisasi Aset Mudah Himpun Dana Triuliunan Rupiah. Jakarta: PT. Elex Media Komputindo, 2007.

[13] I. M. B. Tirthayatra, "Efek Beragun Aset," J. Huk. Pasar Modal, vol. VIII, no. 16, pp. 45-54, 2018.

[14] OECD, "Report of The Informal Consultative Group on The Taxation of Collective Investment Vehicles and Procedures for Tax Relief for Cross-Border Investors on The Granting of Treaty Benefits with Respect to The Income of Collective Investment Vehicles," 2009.

[15] H. Rosdiana and E. S. Irianto, Pengantar Ilmu Pajak: Kebijakan dan Implementasi di Indonesia. Jakarta: Raja Grafindo Pustaka, 2012.

[16] Undang-Undang Nomor 36 Tahun 2008 Tentang Perubahan Keempat atas Undang-Undang 
Nomor 7 Tahun 1983 Tentang Pajak Penghasilan. Republik Indonesia.

[17] Keputusan Direktur Jenderal Pajak Nomor KEP-147/PJ/2003 tentang Pajak Penghasilan atas Penghasilan yang Diterima atau Diperoleh KIK-EBA dan Para Investornya. Republik Indonesia.

[18] Deborah, "Mencermati Isu Withholding Tax atas Marjin KIK-EBA," Analisis Pajak, 2018. https://news.ddtc.co.id/mencermati-isu-withholding-tax-atas-marjin-kik-eba-13853.

[19] Deborah (Tax Practitioner), "Depth Interview," 2020.

[20] C. Hadiputranto (CIC-ABS Representative), "Depth Interview," 2020.

[21] Peraturan Direktur Jenderal Pajak Nomor PER-21/PJ/2014 tentang Perubahan atas Peraturan Direktur Jenderal Pajak Nomor PER-1/PJ/2011 tentang Tata Cara Pengajuan Permohonan Pembebasan dari Pemotongan dan/atau Pemungutan Pajak. Republik Indonesia.

[22] Peraturan Pemerintah Nomor 55 Tahun 2019 tentang Perubahan Kedua atas Peraturan Pemerintah Nomor 16 Tahun 2009 tentang Pajak Penghasilan atas Penghasilan Berupa Bunga Obligasi. Republik Indonesia. 